\title{
Apparent increase in coccolithophore abundance in the subtropical North Atlantic from 1990 to 2014
}

\author{
Kristen M. Krumhardt ${ }^{1}$, Nicole S. Lovenduski ${ }^{2}$, Natalie M. Freeman ${ }^{2}$, and Nicholas R. Bates ${ }^{3}$ \\ ${ }^{1}$ Environmental Studies Program and Institute of Arctic and Alpine Research, University of Colorado Boulder, Boulder, \\ Colorado, USA \\ ${ }^{2}$ Department of Atmospheric and Oceanic Sciences and Institute of Arctic and Alpine Research, University of Colorado \\ Boulder, Boulder, Colorado, USA \\ ${ }^{3}$ Bermuda Institute of Ocean Sciences, Ferry Reach, Bermuda
}

Correspondence to: Kristen M. Krumhardt (kristen.krumhardt@colorado.edu)

Received: 5 November 2015 - Published in Biogeosciences Discuss.: 18 November 2015

Revised: 11 February 2016 - Accepted: 12 February 2016 - Published: 25 February 2016

\begin{abstract}
As environmental conditions evolve with rapidly increasing atmospheric $\mathrm{CO}_{2}$, biological communities will change as species reorient their distributions, adapt, or alter their abundance. In the surface ocean, dissolved inorganic carbon (DIC) has been increasing over the past several decades as anthropogenic $\mathrm{CO}_{2}$ dissolves into seawater, causing acidification (decreases in $\mathrm{pH}$ and carbonate ion concentration). Calcifying phytoplankton, such as coccolithophores, are thought to be especially vulnerable to ocean acidification. How coccolithophores will respond to increasing carbon input has been a subject of much speculation and inspired numerous laboratory and mesocosm experiments, but how they are currently responding in situ is less well documented. In this study, we use coccolithophore (haptophyte) pigment data collected at the Bermuda Atlantic Time-series Study (BATS) site together with satellite estimates (19982014) of surface chlorophyll and particulate inorganic carbon (PIC) as a proxy for coccolithophore abundance to show that coccolithophore populations in the North Atlantic subtropical gyre have been increasing significantly over the past 2 decades. Over 1990-2012, we observe a $37 \%$ increase in euphotic zone-integrated coccolithophore pigment abundance at BATS, though we note that this is sensitive to the period being analyzed. We further demonstrate that variability in coccolithophore chlorophyll $a$ here is positively correlated with variability in nitrate and DIC (and especially the bicarbonate ion) in the upper $30 \mathrm{~m}$ of the water column. Previous studies have suggested that coccolithophore photosynthesis may benefit from increasing $\mathrm{CO}_{2}$, but calcification may even-
\end{abstract}

tually be hindered by low $\mathrm{pH}_{T}(<7.7)$. Given that DIC has been increasing at BATS by $\sim 1.4 \mu \mathrm{mol} \mathrm{kg}{ }^{-1} \mathrm{yr}^{-1}$ over the period of 1991-2012, we speculate that coccolithophore photosynthesis and perhaps calcification may have increased in response to anthropogenic $\mathrm{CO}_{2}$ input.

\section{Introduction}

Coccolithophores are the most abundant type of calcifying phytoplankton in the ocean. Belonging to the phytoplankton group known as haptophytes, coccolithophores generate a substantial fraction of the primary production in many diverse marine environments from cold, sub-polar waters to warm, tropical waters (Thierstein and Young, 2004). Coccolithophores produce calcium carbonate $\left(\mathrm{CaCO}_{3}\right)$ shells that sink to the deep ocean forming chalk deposits and thus are important for global biogeochemical cycling of carbon and climate feedbacks. Furthermore, coccolithophores comprise the base of many marine food webs and are widespread throughout the world ocean (Boyd et al., 2015). Changes in coccolithophore abundance could therefore have far-reaching effects from the ecosystem level to global carbon cycling (Boyd et al., 2015).

Ocean acidification from the gradual oceanic absorption of anthropogenic $\mathrm{CO}_{2}$ has been projected to impact future coccolithophore populations, possibly disrupting the formation and/or dissolution of their $\mathrm{CaCO}_{3}$ shells (e.g., Doney et al., 2009; Mackey et al., 2015). As $\mathrm{CO}_{2}$ is absorbed from the at- 
mosphere, it reacts with water releasing hydrogen ions $\left(\mathrm{H}^{+}\right)$ and increasing dissolved inorganic carbon (DIC). Excess $\mathrm{H}^{+}$ ions and more DIC in the water column lead to a decrease in the carbonate ion $\left(\mathrm{CO}_{3}^{2-}\right)$ concentration in the ocean (for an overview of $\mathrm{CO}_{2}$-carbonate chemistry see Bates et al., 2014). Lower $\mathrm{CO}_{3}^{2-}$ concentrations decrease the saturation state of $\mathrm{CaCO}_{3}$ and could result in lower calcification rates in coccolithophores. Recently, Bach (2015) proposed that a substrate-inhibitor ratio may be a better indicator of potential biocalcification rates. Bicarbonate ions $\left(\mathrm{HCO}_{3}^{-}\right)$are the substrate for calcification in most calcifying organisms, but high concentrations of $\mathrm{H}^{+}$ions can limit calcification. Therefore, a decreasing $\left[\mathrm{HCO}_{3}^{-}\right] /\left[\mathrm{H}^{+}\right]$ratio may eventually hinder calcification, rather than low $\mathrm{CO}_{3}^{2-}$ concentrations. Even so, other factors (e.g., nutrient and light limitation) could exert a stronger control on calcification than carbonate chemistry (Bach et al., 2015). $\mathrm{A} \mathrm{CO}_{3}^{2-}$ saturation state of less than 1 would still, however, cause the dissolution of $\mathrm{CaCO}_{3}$ shells. Speculation of how coccolithophores will respond to increasing DIC and acidification (i.e., the balance between $\mathrm{CaCO}_{3}$ production vs. dissolution) has been the subject of many laboratory and mesocosm studies (e.g., Iglesias-Rodriguez et al., 2008; Schlüter et al., 2014; Riebesell et al., 2007). These, however, have yielded mixed results, highlighting the complexity of biological responses to these changing oceanic conditions.

Numerous laboratory studies indicate that acidification of oceanic waters leads to a decrease in calcification rates for coccolithophores (Riebesell et al., 2000; Sciandra et al., 2003; Delille et al., 2005). However, some recent studies show that coccolithophores increase calcification in response to increasing $\mathrm{CO}_{2}$ or restore calcification rates after an adaptation period under increasing $\mathrm{CO}_{2}$ and warming (e.g., Iglesias-Rodriguez et al., 2008; Schlüter et al., 2014). Indeed, responses to elevated $\mathrm{CO}_{2}$ by different species of coccolithophores vary in all directions, making the extrapolation of these laboratory results to natural populations challenging. How calcifying phytoplankton will react to continually increasing $\mathrm{CO}_{2}$ may vary from region to region in the world's oceans, depending on phytoplankton assemblages (e.g., the dominant species or strain of coccolithophore), available nutrients, and temperature (Sett et al., 2014). Coccolithophore responses to ocean acidification may be species specific or even vary within species (different morphotype responses, see Beaufort et al., 2011).

Differences in physiological mechanisms could play an important role in determining relative phytoplankton abundances under increasing DIC and acidification. For instance, nutrient uptake rates vary between phytoplankton species depending on the affinity of the transport mechanism for its substrate (e.g., phosphate ion). Laboratory experiments on the widespread coccolithophore Emiliania huxleyi have shown this species to have an efficient phosphate uptake system with a low half-saturation constant for phosphate, mak- ing it a superior competitor in phosphate-limited oceanic regions (Riegman et al., 2000). These results have been supported by field data from the subtropical Pacific Ocean (Cortés et al., 2001) and through a combination of field data and modeling in the northeast Atlantic Ocean (Tyrrell and Taylor, 1996). For inorganic carbon uptake for photosynthesis, however, E. huxleyi displays a relatively high halfsaturation constant compared to other phytoplankton (Riebesell, 2004; Rost et al., 2003), indicating that coccolithophores may benefit from increasing atmospheric $\mathrm{CO}_{2}$ absorbed into the ocean. However, there are few in situ or observational studies of coccolithophore responses to increasing anthropogenic carbon (e.g., Feng et al., 2009; Freeman and Lovenduski, 2015).

To test the hypothesis that coccolithophores may be responding positively to additional $\mathrm{CO}_{2}$ inputs, we employed data from the Bermuda Atlantic Time-series Study (BATS), a long-running oceanic time series in the North Atlantic subtropical gyre (Sargasso Sea) located at approximately $31.7^{\circ} \mathrm{N}, 64.2^{\circ} \mathrm{W}$ (Fig. 1). At this site, twice-monthly and monthly hydrographic and biogeochemical measurements have been made since the late 1980s (Fig. 1; Lomas et al., 2010; Bates et al., 2014). The BATS environment is characterized by Ekman downwelling and convergence, which results in an oligotrophic setting (Sarmiento and Gruber, 2006). While this area displays strong summer stratification (mixedlayer depth $\sim 35 \mathrm{~m}$ ), seasonal overturning results in a deep mixing of the water column during winter (mixed-layer depth $\sim 250 \mathrm{~m}$; Steinberg et al., 2001; Lomas et al., 2013). Though oligotrophic oceanic gyres have relatively low productivity compared to other areas of the oceans, they cover vast areas and thus are important on a global scale (Sarmiento and Gruber, 2006). Furthermore, the strong summer stratification experienced in these regions could be indicative of future trends, as increased stratification of the water column is projected with global warming (Gruber, 2011; Giovannoni and Vergin, 2012; Cabré et al., 2015). Thus, understanding phytoplankton dynamics subject to these environmental conditions is essential for accurately forecasting future ocean biogeochemistry.

Pigment analyses have been used to study the distribution, relative abundance, and assemblages of natural phytoplankton populations. Using high performance liquid chromatography (HPLC) to identify the presence and concentration of signature pigments, researchers can obtain relative components of chlorophyll $a(\mathrm{Chl} a$ ) from phytoplankton (Letelier et al., 1993; Wright and van den Enden, 2000; Van Lenning et al., 2004). Coccolithophores, a haptophyte algae, are identified using signature pigments for haptophytes (mainly $19^{\prime}$-hexanoyloxyfucoxanthin), of which coccolithophores are likely the main component (Dandonneau et al., 2006), particularly at BATS (see Sect. 2; Haidar and Thierstein, 2001; Steinberg et al., 2001; Lomas and Bates, 2004). While HPLC pigment analyses can provide a site-specific record of phyto- 


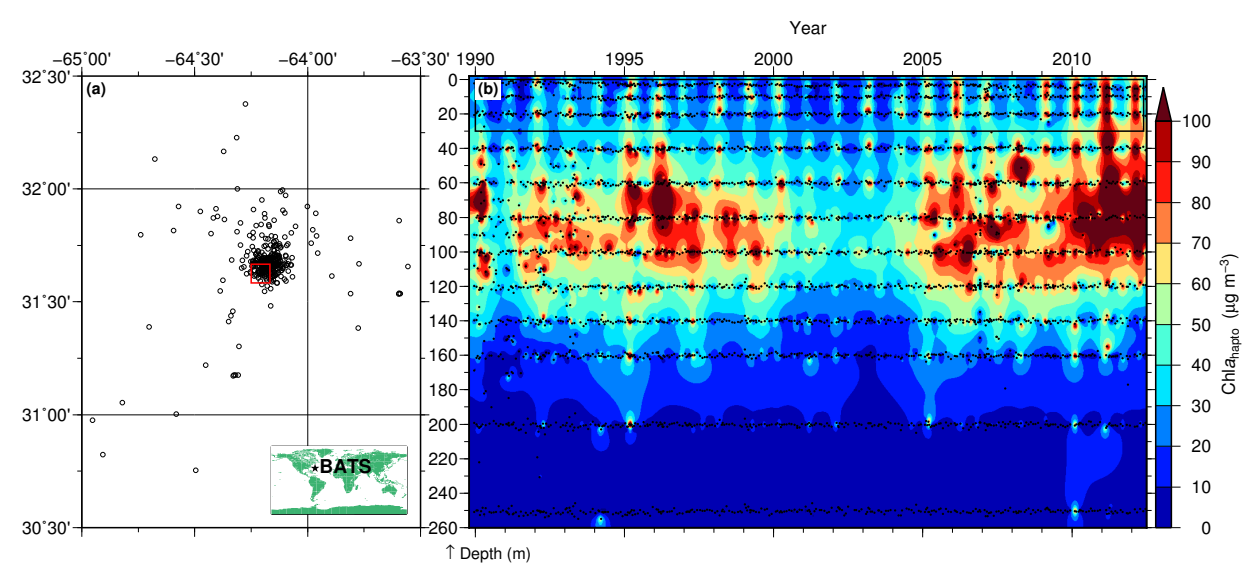

Figure 1. Horizontal (a) and vertical (b) distribution of pigment measurements taken at BATS (black dots) overlaid on a contour plot of HPLC-measured Chl $a_{\text {hapto }}$ at BATS. The red box in (a) shows the PIC grid cell containing the most BATS measurements (PIC data shown in Fig. 8), while the black box in (b) shows the upper $30 \mathrm{~m}$ of measurements used for PIC-Chl $a_{\text {hapto }}$ correlations and correlations presented in Fig. 3.

plankton relative abundance, satellite-based records can provide information at larger spatial scales.

Ocean color remote sensing, through the Sea-viewing Wide Field-of-view Sensor (SeaWiFS; 1997-2010) and the Moderate Resolution Imaging Spectroradiometer (MODIS) Aqua (2002-present) platforms, has revolutionized our understanding of the ecological processes of the upper ocean on a variety of spatial and temporal scales. Satellite-estimated Chl $a$ concentration has been used as a proxy for phytoplankton abundance and biomass since 1978. While most phytoplankton are not very effective light scatterers relative to their surroundings, coccolithophores produce $\mathrm{CaCO}_{3}$ shells that are highly reflective. An understanding of coccolithophorespecific water-leaving radiances and the calcite-specific backscattering cross section allows for the concentration of coccolithophore particulate inorganic carbon (PIC) to be estimated via remote sensing (Gordon et al., 2001; Balch et al., 2005; Balch and Utgoff, 2008). Therefore, satellite estimates of PIC provide a qualitative proxy for coccolithophore abundance.

In this study, we combine pigment data from BATS along with PIC and Chl $a$ measurements from the satellite record to assess recent trends in phytoplankton dynamics in the North Atlantic subtropical gyre, with a focus on coccolithophores. This data suggest that coccolithophore populations in the North Atlantic are increasing. Correlations indicate that they may be responding positively to increasing inorganic carbon from anthropogenic inputs in the upper mixed layer.

\section{Methods}

\subsection{Data sources}

Pigment measurements were obtained from the website of BATS (http://bats.bios.edu), resampled at regular monthly intervals using a linear interpolation between measurements, and converted to relative $\mathrm{Chl} a$ components from different phytoplankton groups as in Letelier et al. (1993). Briefly, each phytoplankton group is associated with signature pigments that have relatively constant ratios with total $\mathrm{Chl} a$. Signature pigment concentrations from each phytoplankton group, obtained via HPLC analysis, were converted to $\mathrm{Chl} a$ concentration using these ratios. This method has been verified in the North Pacific (Letelier et al., 1993) and the North Atlantic subtropical gyres (Andersen et al., 1996). We focused on measurements from the upper water column (top $30 \mathrm{~m}$ ), consistently within the mixed layer (Steinberg et al., 2001; Lomas et al., 2013), but also examined trends and variability integrated over the depth of the euphotic zone $(\sim 140 \mathrm{~m})$ to verify congruence with the top $30 \mathrm{~m}$ of the water column.

Haptophyte pigments specifically were calculated using $19^{\prime}$-hexanoyloxyfucoxanthin $\left(19^{\prime}\right.$-hex $)$ pigments and $19^{\prime}$-butanoyloxyfucoxanthin (19'-but). Coccolithophores and other prymnesiophytes contain $19^{\prime}$-hex and negligible amounts of $19^{\prime}$-but, while some other phytoplankton (e.g., chrysophytes and Phaeocystis) contain significant amounts of both 19'-hex and 19'-but (Zapata et al., 2004; Letelier et al., 1993). Based on the relative concentrations of $19^{\prime}$-but to $19^{\prime}$-hex measured at BATS, we subtracted out the phytoplankton pigment contribution that contains both $19^{\prime}$-hex and 19'-but, as in Letelier et al. (1993), and multiply the remaining $19^{\prime}$-hex concentration by a $19^{\prime}$-hex to Chl $a$ ratio found in calcifying haptophytes (Letelier et al., 1993). The 
result is the haptophyte chlorophyll $a$ fraction, which in this study, we assume to be mainly from coccolithophores. Particularly at BATS, the dominant haptophyte group has been reported to be coccolithophores by, e.g., Lomas and Bates (2004) and Steinberg et al. (2001), but these references offer no direct evidence for this assumption. We did, however, find a significant correlation $\left(p<0.0000001, r^{2}=0.69\right)$ between coccolithophore cell counts published in Haidar and Thierstein (2001) and calculated $\mathrm{Chl} a$ from haptophytes at BATS (Fig. S1 in the Supplement). More generally, Dandonneau et al. (2006) reported that coccolithophores often dominate the haptophyte community in open-ocean environments, such as BATS.

In order to explore whether phytoplankton population dynamics are driven by carbonate chemistry parameters, we used the Mocsy Fortran 90 package (Orr and Epitalon, 2015) to solve the full carbonate chemistry system using available measurements at BATS (Bates et al., 2012). Using dissociation constants from Lueker et al. (2000), carbonate chemistry output from Mocsy agrees with other current carbonate system packages available (Orr et al., 2014). Input includes average concentrations of total alkalinity and DIC along with mean temperature and salinity in the top $30 \mathrm{~m}$. Output includes $\mathrm{pH}_{T}, \mathrm{CO}_{3}^{2-}$ concentration, bicarbonate $\left(\mathrm{HCO}_{3}^{-}\right)$ concentration, and aqueous $\mathrm{CO}_{2}+$ carbonic acid $\left(\mathrm{CO}_{2(\mathrm{aq})}+\right.$ $\mathrm{H}_{2} \mathrm{CO}_{3}=\mathrm{H}_{2} \mathrm{CO}_{3}^{*}$ ).

We used satellite observations of level 3, monthly binned PIC and Chl $a$ from the SeaWiFS (1997-2007; limited data availability after 2007) and MODIS Aqua (2003-2014) on a $9 \mathrm{~km}(5 \mathrm{~min})$ grid obtained from the NASA Ocean Color distributed archive (http://oceancolor.gsfc.nasa.gov/). We calculated the mean satellite-derived PIC concentration in the BATS region that contains $>95 \%$ of pigment measurements (Fig. 1a).

\subsection{Statistical analyses}

\subsubsection{Correlations}

In order to identify correlations of phytoplankton pigment abundance across different species, with local environmental variables, and with satellite products, we performed correlation analysis on linearly detrended and deseasonalized (1-year boxcar smoothing) anomalies. Correlations between the main Chl $a$ phytoplankton fractions present at BATS (Prochlorococcus, Synechococcus, haptophytes, and diatoms) were calculated for a variety of oceanic measurements hypothesized to influence phytoplankton abundance: DIC, alkalinity, inorganic nitrogen concentrations, temperature, salinity, and carbonate chemistry variables (see above section on carbonate chemistry). We also explored possible correlations between Chl $a$ phytoplankton fractions and the mixed-layer depth (MLD). We used two methods for calculating MLD. MLD $\mathrm{D}_{\text {sigma }}$ was determined to be where the potential density anomalies (sigma-theta) at depth dis- played $\mathrm{a}>0.125 \mathrm{~kg} \mathrm{~m}^{-3}$ difference from surface waters, while $M L D_{\text {temp }}$ was calculated as the location of $0.5^{\circ} \mathrm{C}$ change in temperature from the surface (Monterey and Levitus, 1997). Mean density and temperature measurements within the top $10 \mathrm{~m}$ of the water column were used for surface values. We also tested correlations with the monthly mean North Atlantic Oscillation (NAO) index, obtained from NOAA National Weather Service Climate Prediction Center (http://www.cpc.ncep.noaa.gov/data/teledoc/nao.shtml).

\subsubsection{Trends}

In order to quantify temporal trends in pigment concentrations, biogeochemical measurements, and satellite data, we calculated the slope of a straight line that best fit the time series in a least-squares sense. When comparing trends in pigments with trends in biogeochemical measurements at BATS, we used the average values over the top $30 \mathrm{~m}$ of the water column. Satellite Chl $a$ and PIC trend analysis was performed on a grid cell basis.

\section{Results}

\subsection{Chl $a_{\text {hapto }}$ at BATS}

Chl $a$ from haptophytes (Chl $a_{\text {hapto }}$; assumed to be primarily from cocccolithophores; see Sect. 2) is present throughout the euphotic zone at BATS and displays a pronounced seasonal cycle. Concentrations of Chl $a_{\text {hapto }}$ surpassed $100 \mu \mathrm{g} \mathrm{m}^{-3}$ during periods of high abundance, with $\sim$ $35 \mu \mathrm{g} \mathrm{Chl} a_{\text {hapto }} \mathrm{m}^{-3}$ during periods of relatively low abundance, such as between 2000 and 2004 (Fig. 1b). The bulk of haptophyte pigments occurred around $\sim 80 \mathrm{~m}$ of depth, but pigments were also abundant in the upper $30 \mathrm{~m}$, especially during spring. Haptophyte pigment concentration is low below depths of $\sim 140 \mathrm{~m}$. During the mid-90s and last 6 years of the data set, $\mathrm{Chl} a_{\text {hapto }}$ was more concentrated, especially in the upper $30 \mathrm{~m}$ of the water column (Fig. 1b).

Haptophytes comprise roughly $30 \%$ of the $\mathrm{Chl} a$ in the upper $30 \mathrm{~m}$ of the water column at BATS (Fig. 2), a percentage that persists from the start of measurements $(\sim 1990)$ to the end of our data set $(\sim 2012)$. However, a period of low haptophyte abundance occurred between 2000 and 2004, reducing their relative contribution to $\mathrm{Chl} a$ to $15 \%$. Synechococcus $\mathrm{Chl} a$ is variable, ranging from 20 to $70 \%$ of the total Chl $a$ in the upper $30 \mathrm{~m}$. Unfortunately, signature pigment concentrations necessary to calculate Synechococcus Chl $a$ were missing from the BATS data set at the beginning of our time series as well as during a 5-year segment from $\sim 1997$ to $\sim 2002$ (shown as hatched area in Fig. 2). In contrast to generally high Synechococcus and haptophyte pigment abundance, Prochlorococcus and diatom pigments contribute relatively small fractions to the total Chl $a$ in the upper $30 \mathrm{~m}$. Correlations with potentially influential oceanographic drivers can aid in explaining variable abundance of 


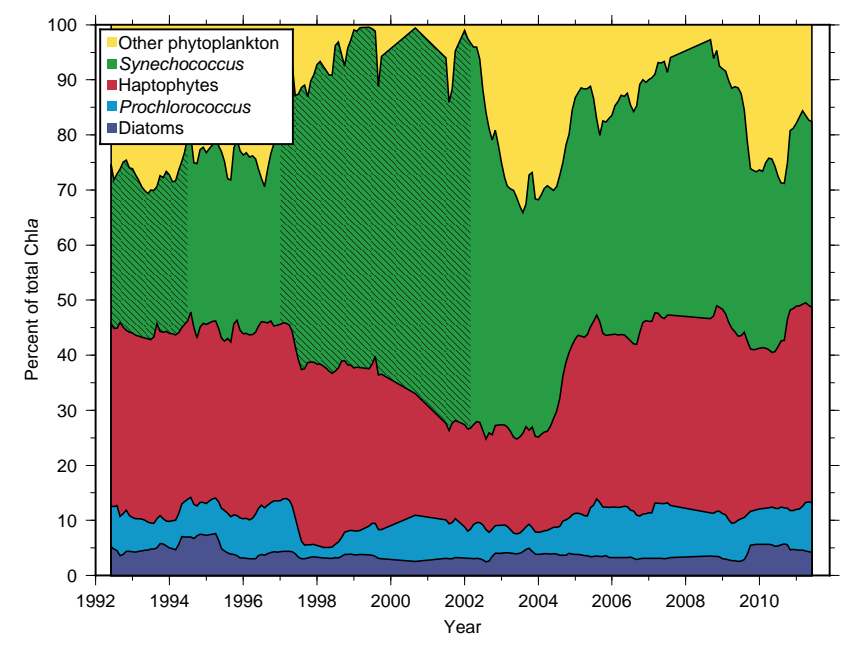

Figure 2. Percent of Chl $a$ from main phytoplankton groups at BATS from 1992 to 2012 in the top $30 \mathrm{~m}$ of the water column derived from signature pigment and $\mathrm{Chl} a_{\text {total }}$ concentrations, deseasonalized with a 1-year boxcar filter (purple is diatoms, blue is Prochlorococcus, red is haptophytes, green is Synechococcus, yellow is other phytoplankton). Hatched area indicates missing pigment data for Synechococcus.

different phytoplankton Chl $a$ fractions in these surface waters.

\subsection{Correlations of $\mathrm{Chl} a$ components with oceanographic measurements at BATS}

Correlation coefficients between detrended, deseasonalized anomalies of Chl $a_{\text {hapto }}$, Chl $a$ from Synechococcus (Chl $\left.a_{\text {syn }}\right)$, Chl $a$ from Prochlorococcus (Chl $a_{\text {pro }}$ ), and Chl $a$ from diatoms (Chl $\left.a_{\text {diatoms }}\right)$ and anomalies in other oceanographic measurements/indices are presented in Fig. 3. Chl $a_{\text {hapto }}$ shows strong positive correlations with DIC and $\mathrm{HCO}_{3}^{-}$(explaining nearly $20 \%$ of the variability). Chl $a_{\text {pro }}$ showed similar, but somewhat weaker, correlations with DIC and $\mathrm{HCO}_{3}^{-}$. Conversely, $\mathrm{Chl} a_{\text {syn }}$ displayed a strong negative correlation with DIC and $\mathrm{HCO}_{3}^{-}$(Fig. 3). All phytoplankton pigment groups, except Synechococcus, were positively correlated with nitrate $\left(\mathrm{NO}_{3}^{-}\right)$variability (measurements also include nitrite, $\mathrm{NO}_{2}^{-} ; \mathrm{NO}_{3}^{-}+\mathrm{NO}_{2}^{-}$is referred to hereinafter as $\mathrm{NO}_{3}^{-}$). $\mathrm{CO}_{3}^{2-}$ concentration, the saturation state of aragonite $\left(\Omega_{\mathrm{arag}}\right)$, and temperature were negatively correlated with Chl $a_{\text {hapto }}$, opposite to Chl $a_{\text {syn }}$. Indeed, Synechococcus and haptophyte pigments display inverse correlations for nearly every variable tested, including temperature (Fig. 3).

Temperature is negatively correlated with Chl $a_{\text {hapto }}$ (as well as $\mathrm{Chl} a_{\text {pro }}$ and $\left.\mathrm{Chl} a_{\text {diatoms }}\right)$ and positively correlated with Chl $a_{\text {syn }}$ (Fig. 3). Furthermore, when the NAO index is in a positive phase, temperatures over this region of the North Atlantic are generally warmer (Visbeck et al., 2001). Therefore, in line with the temperature correlations, the NAO in-

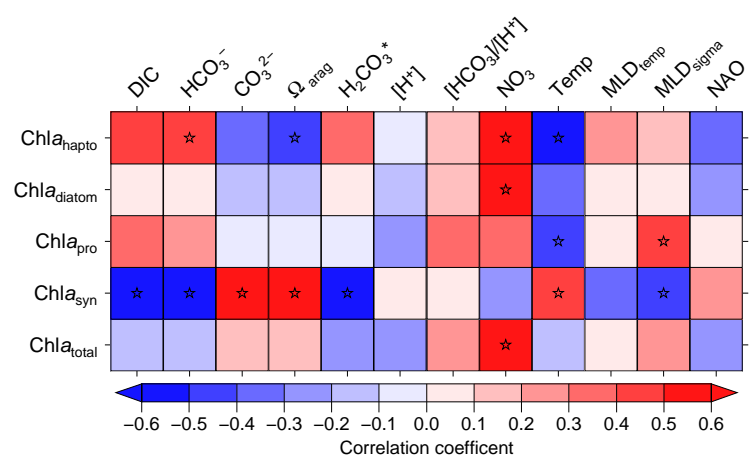

Figure 3. Correlation coefficients between Chl $a$ components and various oceanographic measurements made in the upper $30 \mathrm{~m}$ of the water column at BATS, NAO index, calculated mixed-layer depth (MLD; see Sect. 2) and derived carbonate chemistry parameters. Stars indicate the absolute value of the correlation coefficient is greater than 0.4 .

dex is negatively correlated with $\mathrm{Chl} a_{\text {hapto }}$, opposite again to Chl $a_{\text {syn }}$. MLD, an indicator of both temperature and nutrient availability, shows corresponding correlations with $\mathrm{Chl} a$ components. When the MLD is deeper, there is more Chl $a_{\text {hapto }}$ and less Chl $a_{\text {syn }}$. Both methods of calculating MLD (MLD temp and MLD $_{\text {sigma }}$ ) showed similar correlations (Fig. 3).

\subsection{Fluctuations in chlorophyll $a$ from different phytoplankton groups}

Haptophyte and Synechococcus pigments generally show opposing correlations with the variables tested (Fig. 3). This is supported by the opposing dominance of either Synechococus or haptophyte Chl $a$ throughout the time series (Fig. 4). Indeed Chl $a_{\text {hapto }}$ and $\mathrm{Chl} a_{\text {syn }}$ show a significant negative correlation $(p<0.00001)$. During periods of low haptophyte pigment abundance (e.g., 2000-2004), Synechococcus pigments dominate the water column. Later in the time series, however, Synechococcus pigments decline and haptophyte pigments increase. Prochlorococcus pigments (mostly low-light Prochlorococcus; see Discussion) at BATS reside mostly in the deep chlorophyll maximum at $\sim 100 \mathrm{~m}$ of depth and are a relatively minor component of the Chl $a$ in the upper $30 \mathrm{~m}$ of the euphotic zone. Diatom presence, usually associated with cold, high nutrient environments, is sporadic and generally low in this oligotrophic oceanic region of the subtropical North Atlantic, according to their signature pigments (Fig. 4).

In general, pigment analyses indicate that Synechococcus and haptophytes are the most abundant phytoplankton groups at BATS (Figs. 2 and 4). However, the category classified as other (includes chrysophytes, dinoflagellates, and prasinophytes, among others) in Fig. 3 comprises a large portion $(>30 \%)$ of the phytoplankton biomass during certain periods, indicating certain conditions may favor neither 


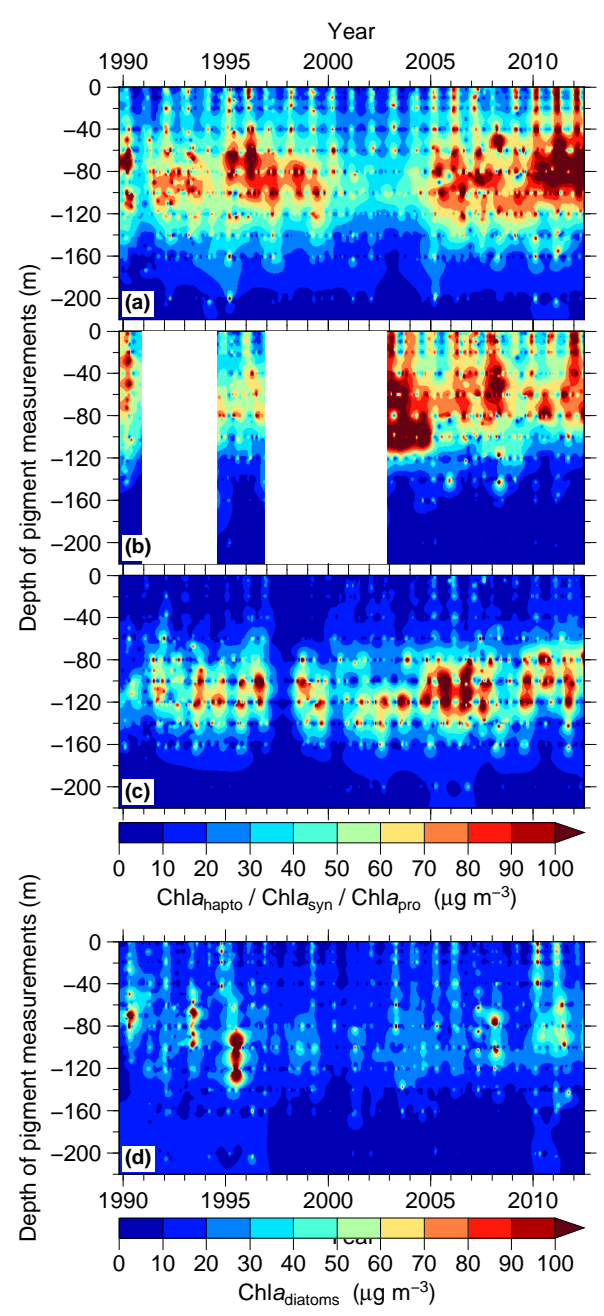

Figure 4. Temporal evolution of the vertically resolved Chl $a$ concentration from the main phytoplankton present at BATS derived from signature pigments from 1990 to 2012: (a) Chl $a_{\text {hapto, }}$

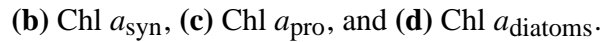

Synechoccocus nor haptophytes. The opposing correlations Synechoccocus and haptophyte pigments exhibit with DIC, $\mathrm{HCO}_{3}^{-}, \mathrm{CO}_{3}^{2-}, \mathrm{NO}_{3}^{-}$and temperature could lead to interesting trends in phytoplankton abundance in an ocean increasingly influenced by anthropogenic climate change.

\subsection{Trends in Chl $a_{\text {hapto }}$ and total $\mathrm{Chl} a$ at BATS}

A time series of $\mathrm{Chl} a_{\text {hapto }}$ at BATS shows that haptophytes (mainly coccolithophores; see Sect. 2) have been increasing significantly since 1990 ( $p<0.01$ for $30 \mathrm{~m}$ integral; $p<0.001$ for $140 \mathrm{~m}$ integral; Fig. 5a, b). Mean concentration of Chl $a_{\text {hapto }}$ in the upper $30 \mathrm{~m}$ of the water column has increased by $0.848 \mu \mathrm{g} \mathrm{m}^{-3} \mathrm{yr}^{-1}$ (standard error $=0.332$ ), corresponding to a $68 \%$ increase over the course of the BATS time series (1991-2012; an overall increase of $17.8 \mu \mathrm{g} \mathrm{m}^{-3}$ ), while the $140 \mathrm{~m}$ integral of $\mathrm{Chl} a_{\text {hapto }}$ has increased by
$0.103 \mathrm{mg} \mathrm{m}^{-2} \mathrm{yr}^{-1}$ (standard error $=0.0307$ ) corresponding to a $37 \%$ increase (an overall increase of $2.2 \mathrm{mg} \mathrm{m}^{-2}$ ). We assess the sensitivity of these trends to interannual variability by performing trend calculations for a range of start and end years over the time series. The resulting trend pattern shown in Fig. 7a shows mostly positive trends in Chl $a_{\text {hapto, }}$ except for end years in the 2000-2004 period. Total chlorophyll $a$ (Chl $\left.a_{\text {total }}\right)$ also shows a significant positive trend over the time series ( $p<0.05$ for $30 \mathrm{~m}$ integral; $p<0.001$ for $140 \mathrm{~m}$ integral; Fig. 6; upper right corner of Fig. 7c). Figure $7 \mathrm{c}$ shows trends in Chl $a_{\text {total }}$ for a range of start and end years, displaying a different pattern than that of the trends in the $\mathrm{Chl} a_{\text {hapto }}$ component of $\mathrm{Chl} a$. For instance, for end years in the 2000-2004 period, Chl $a_{\text {total }}$ shows positive trends (but nonsignificant), whereas $\mathrm{Chl} a_{\text {hapto }}$ shows significant negative trends (Fig. 7). Mean Chl $a$ in the upper $30 \mathrm{~m}$ primarily exhibits negative trends in the later part of the time series and most trends in Chl $a$ are nonsignificant (Fig. 7c). Unfortunately, missing Synechococcus pigment data did not allow for long-term trend analysis of this group of phytoplankton (see hatched area in Fig. 2 and white area in Fig. 4).

In line with the results of our correlation analysis, the trends in $\mathrm{HCO}_{3}^{-}$for various start and end years show a similar pattern to the trends in Chl $a_{\text {hapto }}$ (Fig. 7b): mostly positive trends with slightly negative (but nonsignificant) trends in $\mathrm{HCO}_{3}^{-}$concentration for end year in the 2000-2004 period, a low point in haptophyte pigments. Conversely, the trend pattern for the substrate-inhibitor ratio, $\left[\mathrm{HCO}_{3}^{-}\right] /\left[\mathrm{H}^{+}\right]$, is distinctly different from that of $\mathrm{Chl} a_{\text {hapto }}$, exhibiting all negative trends (Fig. 7d). Trends in Chl $a_{\text {hapto }}$, assumed here to be mainly representative of coccolithophores (see Sect. 2), can be further corroborated with PIC measurements from the satellite record.

\subsection{Relating BATS pigment data to satellite products}

Significant correlations were detected between Chl $a_{\text {hapto }}$ (30 m integral) measured at BATS and PIC derived from each satellite. The SeaWiFS-derived PIC correlated somewhat better with Chl $a_{\text {hapto }}$ than MODIS-derived PIC (SeaWiFS PIC-Chl $a_{\text {hapto }} p=0.0075, r^{2}=0.19$ vs. MODIS PICChl $a_{\text {hapto }} p=0.050, r^{2}=0.12$ ). This difference is likely inherent in the different algorithms used to estimate PIC from each satellite (see following paragraph). Nevertheless, these correlations demonstrate correspondence between $\mathrm{Chl} a_{\text {hapto }}$ measurements and satellite PIC, both of which relate to relative coccolithophore abundance.

Two radiance-based PIC algorithms can be used to relate water-leaving radiance to calcite absorption and scattering properties: a two-band algorithm (Balch et al., 2005) and a three-band algorithm (Gordon et al., 2001). The North Atlantic subtropical gyre exhibits relatively low PIC concentrations year-round. During the SeaWiFS-MODIS overlap period (2003-2007), PIC estimated from the two satellites revealed stark differences (Fig. 5c), possibly explained by the 


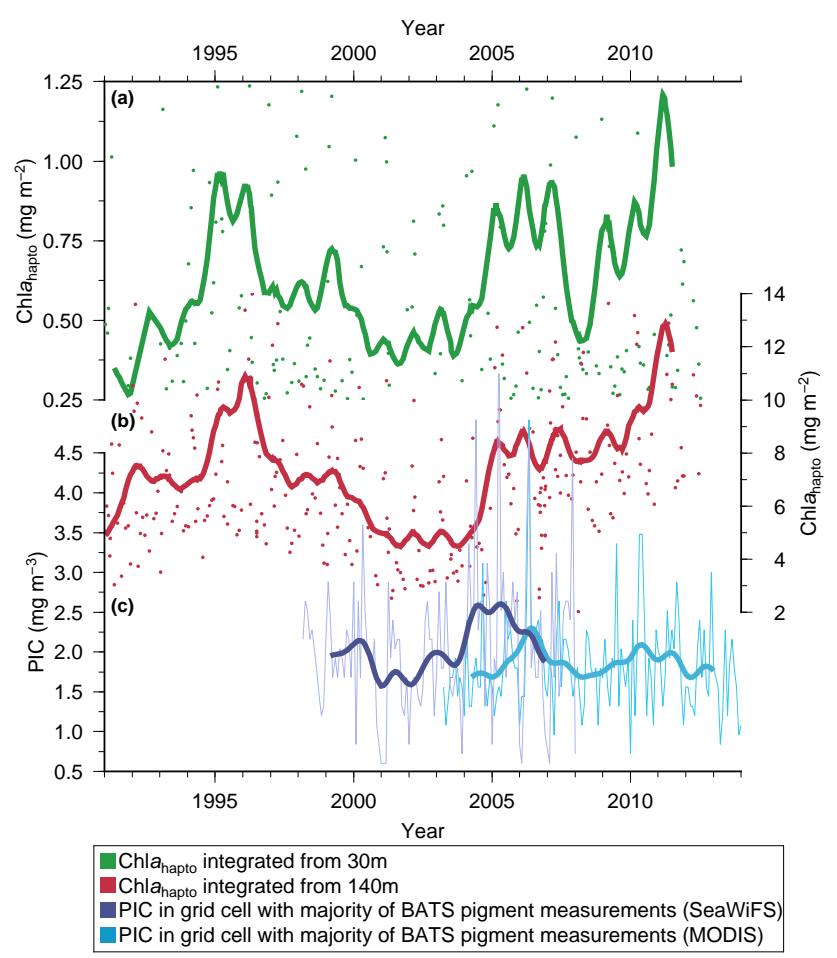

Figure 5. Chl $a_{\text {hapto }}$ measured at BATS and satellite-derived PIC. Chl $a_{\text {hapto }}$ integrated from $30 \mathrm{~m}$ is shown in (a), while Chl $a_{\text {hapto }}$ integrated from $140 \mathrm{~m}$ depth is shown in (b). PIC data shown in (c) were obtained from the 5 min satellite grid cell with the most BATS measurements (see Fig. 1). Bolder lines represent a 2-year Gaussian filter on the data. We restricted the $y$ axes in panels (a) and (b) to highlight the filtered data; see Fig. S3 to view all unfiltered data points.

differences in algorithm performance in this region (i.e., sensitivity to low/background PIC concentrations). The low correspondence between the two estimates of PIC prevented the generation of a single, merged PIC time series. We therefore report trends in PIC separately over the respective satellite eras (Fig. 8).

Chl $a$ measured at BATS (30 m integral) and Chl $a$ derived by satellite were significantly correlated $(p<0.01$, $\left.r^{2}=0.16\right)$. In this case, Chl $a$ measured by satellite displayed good correspondence between the two satellite eras and could be merged into one time series. Following the regression technique of Brown and Arrigo (2012), we generated one continuous record of $\mathrm{Chl} a$ from 1998 to 2014 by applying linear regression over the 2003-2007 SeaWiFSMODIS overlap period to predict these variables from 2008 to 2014 (Fig. 6c).

\subsection{Regional trends in satellite PIC and Chl $a$}

Linear trends in PIC derived from satellite observations are positive for most of the North Atlantic subtropical gyre (Fig. 8). Nearly all significant trends $(p<0.05)$ in PIC con-

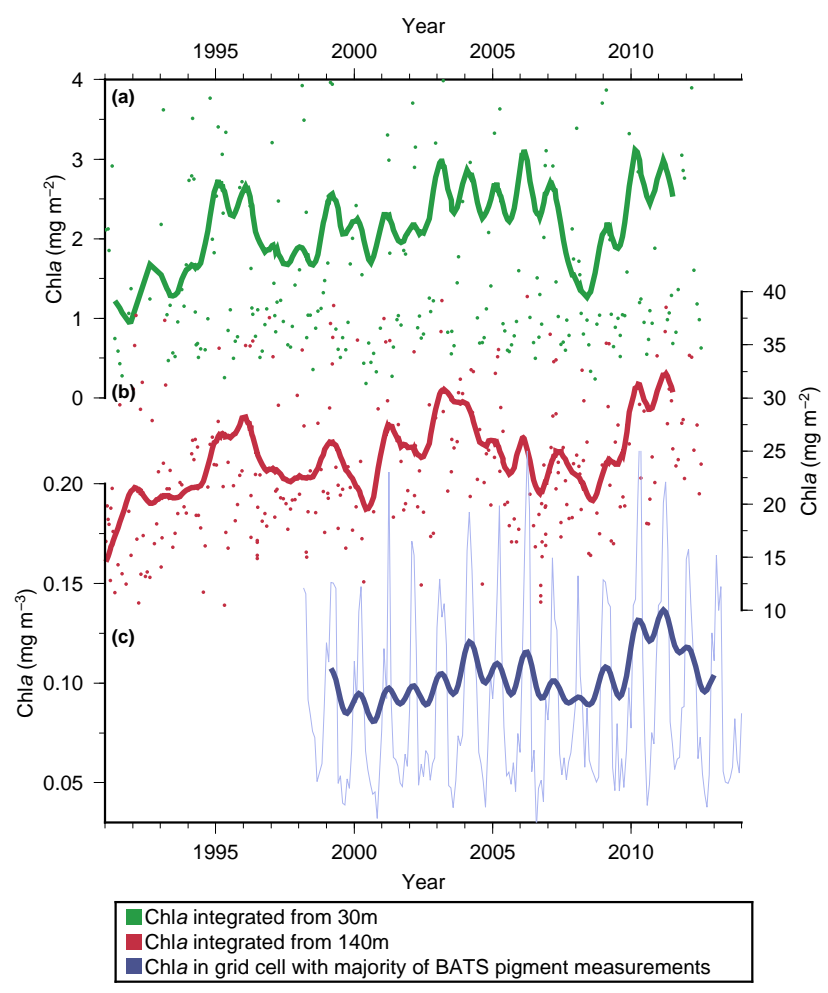

Figure 6. Chl $a_{\text {total }}$ measured at BATS and satellite-derived Chl $a$. Chl $a_{\text {total }}$ integrated from $30 \mathrm{~m}$ is shown in (a), while Chl $a_{\text {total }}$ integrated from $140 \mathrm{~m}$ depth is shown in (b). Chl $a$ data shown in (c) were obtained from the $5 \mathrm{~min}$ satellite grid cell with the most BATS measurements (see Fig. 1). Bolder lines represent a 2-year Gaussian filter on the data. We restricted the $y$ axes in panels (a) and (b) to highlight the filtered data; see Fig. S4 to view all unfiltered data points.

centration are positive, especially during the MODIS era (Fig. 8c, d; 1998-2007 for SeaWiFS and 2003-2014 for MODIS). However, unlike at the BATS site, Chl $a$ does not appear to be increasing in most of the gyre (Fig. 9). There are slight positive trends in $\mathrm{Chl} a$ around the BATS region (Fig. 9a), but these are not statistically significant (Fig. 9b). Indeed, most of the North Atlantic subtropical gyre shows a slight negative trend in $\mathrm{Chl} a$ or no trend at all. A trend of a subset of the satellite Chl $a$ from 1998 to 2012 shows a slight, but nonsignificant, upward trend in Chl $a$ in the BATS region (Fig. 1; $0.0009 \mathrm{mg} \mathrm{m}^{-3} \mathrm{yr}^{-1}, p>0.05$ ), just as the corresponding grid box for Chl $a$ at BATS in Fig. 7 .

\section{Discussion}

\subsection{Phytoplankton dynamics at BATS}

In this study, we observed that coccolithophore populations, based on pigment data for haptophytes, are increasing at BATS and are positively correlated with DIC and $\mathrm{HCO}_{3}^{-}$ (Figs. 1b, 3, 7a). We observed opposite correlations for DIC 

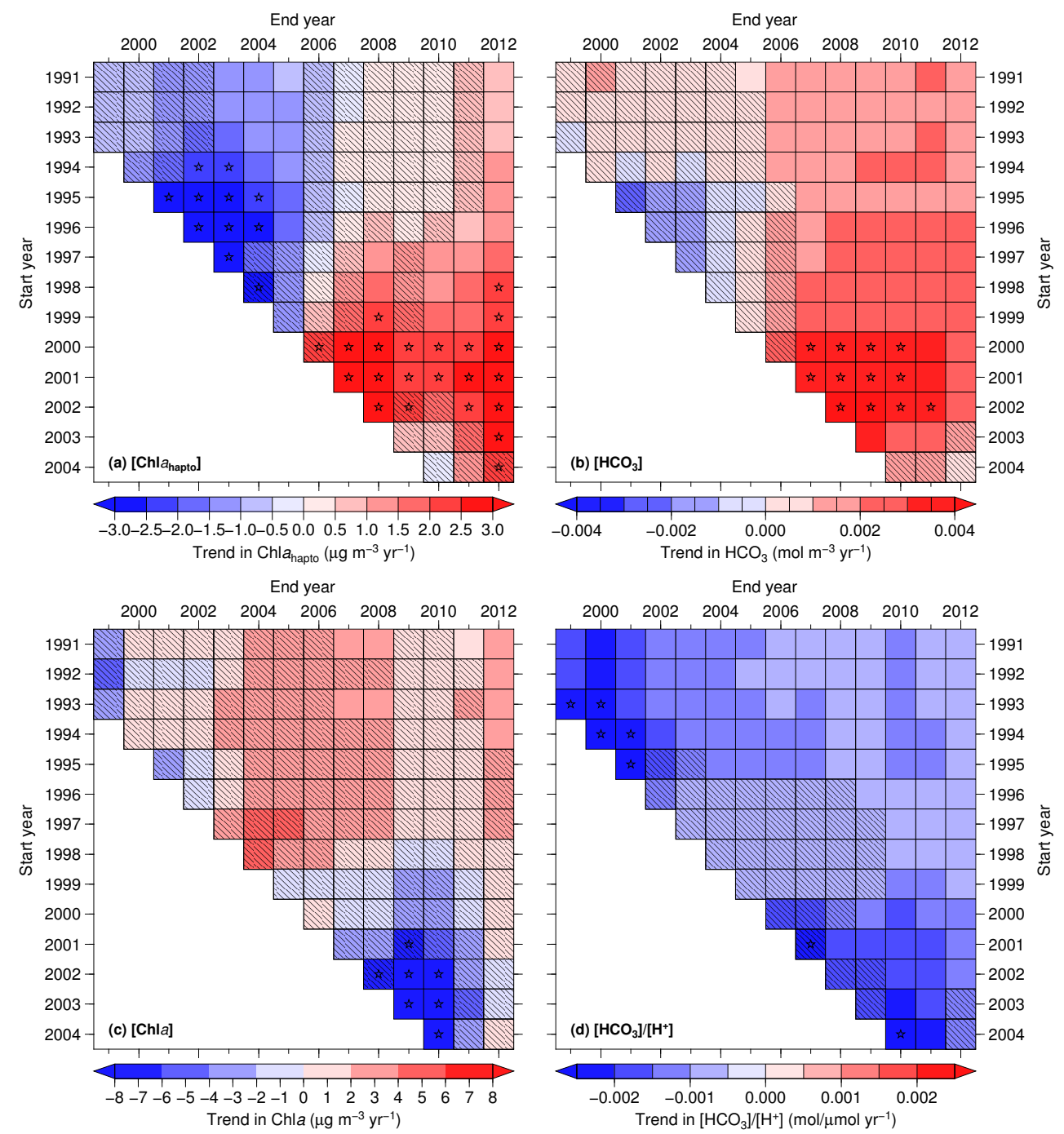

Figure 7. Linear trends for a range of start and end years in (a) $\mathrm{Chl} a_{\text {hapto }}$, (b) $\mathrm{HCO}_{3}^{-}$, (c) $\mathrm{Chl} a$, and (d) ratio of $\mathrm{HCO}_{3}: \mathrm{H}^{+} . \mathrm{All}_{\text {trends are }}$ based on mean concentrations measured at BATS in the upper $30 \mathrm{~m}$ of the water column. Boxes with hatch lines demarcate nonsignificant trends. Stars indicate absolute values of trends are greater than $0.2 \mu \mathrm{g} \mathrm{m}^{-3} \mathrm{yr}^{-1}$ for Chl $a_{\text {hapto }}, 0.003 \mathrm{~mol} \mathrm{~m}^{-3} \mathrm{yr}^{-1} \mathrm{for} \mathrm{HCO}_{3}^{-}, 6 \mu \mathrm{g} \mathrm{m}^{-3} \mathrm{yr}^{-1}$

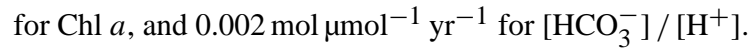

and $\mathrm{HCO}_{3}^{-}$with Synechococcus, the other major member of the phytoplankton community at BATS. Some studies have suggested that photosynthesis and growth of the coccolithophore, E. huxleyi, is carbon limited and could possibly benefit from increasing $\mathrm{CO}_{2}$ (Riebesell, 2004; Rost et al., 2003; Bach et al., 2013). Since $\mathrm{CO}_{2(\mathrm{aq})}$ and $\mathrm{HCO}_{3}^{-}$concentrations increase with increasing DIC/ocean acidification, both photosynthesis and calcification could be stimulated in coccolithophores, which primarily use $\mathrm{CO}_{2}$ for photosynthesis and $\mathrm{HCO}_{3}^{-}$for calcification (Bach et al., 2013). The results presented in this study support the hypothesis that coccolithophores are responding positively to increasing carbon availability, perhaps increasing their competitive ability in oligotrophic settings such as BATS. However, a threshold $\mathrm{H}^{+}$ ion concentration could be reached with further ocean acidification, eventually constraining coccolithophore growth.

Synechococcus, on the other hand, was negatively correlated with increasing carbon in the upper mixed layer and positively correlated with temperature. In laboratory experiments, Synechococcus showed only a slight, non-significant increase in growth rate under elevated $\mathrm{CO}_{2}$ conditions, but increased growth 2.3-fold with increasing $\mathrm{CO}_{2}$ and temperature (Fu et al., 2007). Sea surface temperature in the upper $30 \mathrm{~m}$ at BATS has not increased significantly over the time period of this study $\left(0.04{ }^{\circ} \mathrm{C} \mathrm{yr}^{-1}\right.$ trend, $\left.p=0.22\right)$. However, positive temperature anomalies were recorded during the 2000-2004 period, a period of increased Synechococcus pigment abundance (and low haptophyte pigment abundance). 

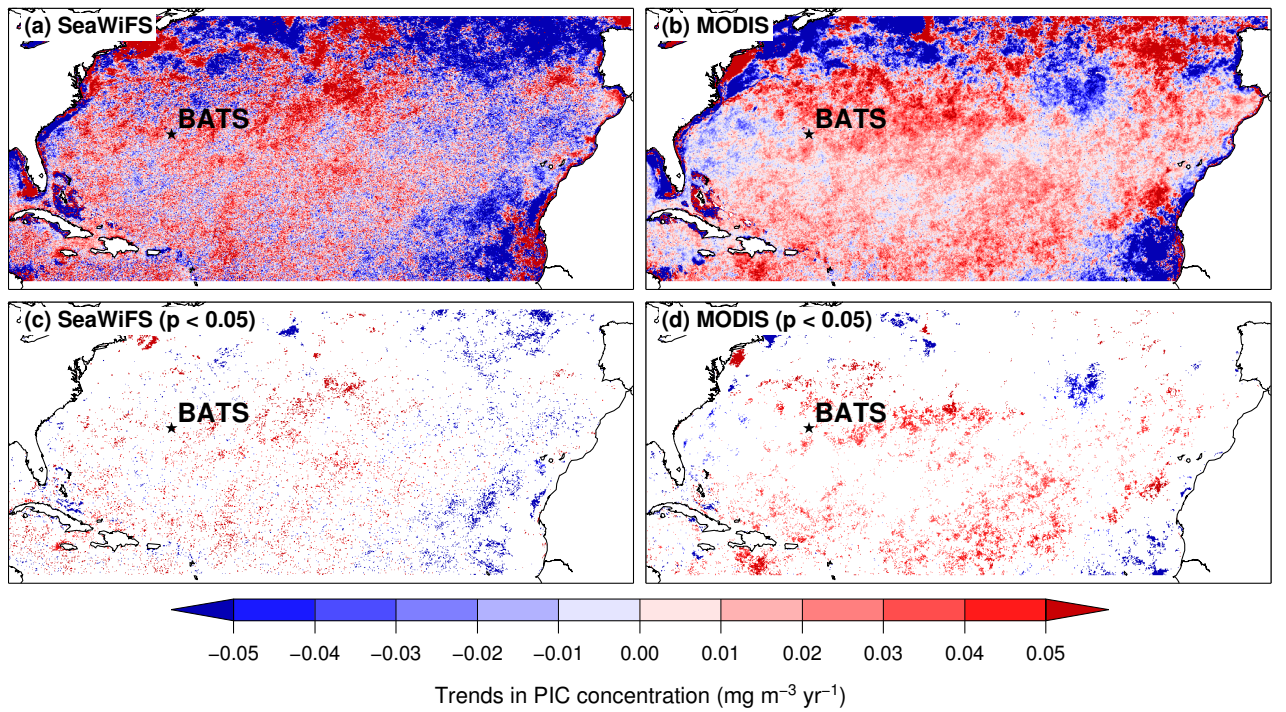

Figure 8. Trends in PIC concentration derived from satellite data for (a, c) SeaWiFS (1998-2007), and (b, d) MODIS (2003-2014). Bottom panels shows significant trends $(p<0.05)$.
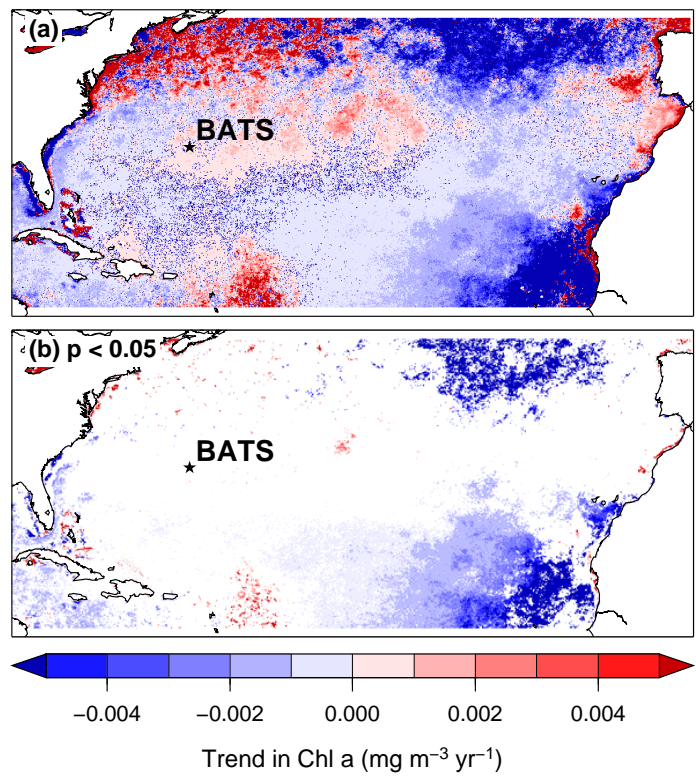

Figure 9. Trends in Chl $a$ concentration derived from merged satellite records: SeaWiFS and MODIS (1998-2014). The bottom map (b) shows significant trends $(p<0.05)$.

Conditions that could favor Synechococcus may eventually arise with further warming, increasing the competitive ability of Synechococcus.

In order to examine redundancy in our correlations, we performed multiple linear regressions between $\mathrm{Chl} a_{\text {hapto }}$ and several of the driver variables with which it showed the strongest correlations (not shown). When DIC and $\mathrm{HCO}_{3}^{-}$ were regressed together with $\mathrm{Chl} a_{\text {hapto }}$, all the statistical power of DIC was removed, indicating that $\mathrm{HCO}_{3}^{-}$is the primary driver of the two for $\mathrm{Chl} a_{\text {hapto }}$ variability. Furthermore, when temperature and $\mathrm{NO}_{3}^{-}$were regressed together with Chl $a_{\text {hapto }}$, the statistical effect of temperature was removed. This indicates that temperature is not a controlling factor for coccolithophore variability, but rather is a proxy for nutrient concentration in relation to coccolithophore growth. A multiple linear regression of $\mathrm{Chl} a_{\text {hapto }}$ with both $\mathrm{HCO}_{3}^{-}$and $\mathrm{NO}_{3}^{-}$ explained $>50 \%$ of the variance in Chl $a_{\text {hapto }}\left(r^{2}=0.52\right)$. Other factors, such as competition or grazing, could perhaps account for some of the remaining variability. Both $\mathrm{HCO}_{3}^{-}$ and $\mathrm{NO}_{3}^{-}$have increased significantly over this time period $(p<0.001)$. However, $\mathrm{NO}_{3}^{-}$measurements are highly variable and near zero, making their accuracy questionable, and the trend is only significant if the last 2 years are included in the time series (Fig. S2). This is in contrast to $\mathrm{HCO}_{3}^{-}$, which shows largely positive trends over this time period matching quite well with those of $\mathrm{Chl} a_{\text {hapto }}$ (Fig. 7).

The positive trend in $\mathrm{HCO}_{3}^{-}$concentration in the upper mixed layer of the water column at BATS is most likely due to increasing absorption of anthropogenic $\mathrm{CO}_{2}$ from the atmosphere. The upper $30 \mathrm{~m}$ of the water column is particularly inundated with anthropogenic $\mathrm{CO}_{2}$ in the North Atlantic (Sabine et al., 2004; Bates et al., 2012). From 1991 to 2012, DIC concentration in the upper $30 \mathrm{~m}$ at BATS increased by a rate of $1.4 \mu \mathrm{mol} \mathrm{kg}^{-1} \mathrm{yr}^{-1}$, which is roughly the expected rate of increase given the rise in atmospheric $\mathrm{CO}_{2}$ (see Chapter 10 in Sarmiento and Gruber, 2006). Increasing inorganic carbon supply could also be accompanied by warmer sea surface temperatures, increased stratification, and decreased nutrient supply over the next century (Cabré et al., 2015). Enriched coccolithophore growth by this additional carbon, as 
well as other predicted oceanic changes with global warming, could lead to shifts in phytoplankton community structure at BATS.

Coccolithophores are not the only phytoplankton that may be responding positively to additional inorganic carbon. Trichodesmium, the filamentous $\mathrm{N}_{2}$-fixing cyanobacteria, has been shown to increase growth and $\mathrm{N}_{2}$ fixation under increasing $\mathrm{CO}_{2}$ (Hutchins et al., 2007), yet other drivers, such as sea surface temperature, nutrients, and species diversity, tend to exert more control on their growth in situ (Snow et al., 2015; Gradoville et al., 2014). Trichodesmium has been reported to be a common component of the phytoplankton assemblages in the subtropical North Atlantic (Carpenter et al., 2004; Agawin et al., 2013; Orcutt et al., 2001), but was not specifically resolved in this study. Trichodesmium contain a similar suite of pigments as Synechococcus (Carpenter et al., 1993; Andersen et al., 1996), and therefore could be included in the $\mathrm{Chl} a_{\text {syn }}$ fraction of our calculations. This would aid to explain the negative correlation between $\mathrm{Chl} a_{\mathrm{syn}}$ and $\mathrm{NO}_{3}^{-}$ (Fig. 3), and further explain why $\mathrm{Chl} a_{\text {syn }}$ is more abundant than Chl $a_{\text {hapto }}$ in the upper water column during warmer, more stratified periods.

Whatever the exact components of Chl $a_{\text {syn }}$, Chl $a_{\text {hapto }}$ generally shows opposing abundance with this group. We hypothesize that when the Synechococcus component ( $\sim 40 \%$ of Chl $a$ on average at BATS) is abundant (perhaps due to a positive temperature anomaly), photosynthesis accompanying an increase in Synechoccocus draws down DIC (thus, $\mathrm{HCO}_{3}^{-}$). Low DIC could provoke carbon limitation of the coccolithophore population (Riebesell, 2004; Rost et al., 2003), hindering their competitive ability. Overall, however, the increase in DIC experienced at BATS during the past 2 decades could lead to slightly increased growth rates of coccolithophores (Riebesell, 2004; Rost et al., 2003), perhaps bolstering their competitive ability within the phytoplankton community. If coccolithophores are becoming more competitive at BATS due to a lessening of carbon limitation, then they could continue to exert greater competitive stress on Synechococcus, which appear to be competing with coccolithophores for a similar niche. However, if the surface waters continue to warm in this region of the Atlantic, as predicted (Cabré et al., 2015), then Synechococcus could regain its competitive edge. Furthermore, increasing $\mathrm{H}^{+}$ion concentrations could eventually constrain coccolithophore growth (Bach et al., 2013, 2015). Small changes in DIC, nutrients, $\mathrm{pH}$, or temperature could, in combination, influence which phytoplankton group (Synechococcus or haptophytes) dominate at any given time at BATS.

The Prochlorococcus group, designated by $\mathrm{Chl} a_{\text {pro, }}$, shows similar correlations with oceanic driver variables as for Chl $a_{\text {hapto }}$ (Fig. 3). Prochlorococcus have been shown to lack a $\mathrm{CO}_{2(\mathrm{aq})}$ uptake mechanism and therefore rely on $\mathrm{HCO}_{3}^{-}$uptake for photosynthesis (Badger and Price, 2003), possibly explaining similar behavior to coccolithophores (also positively correlated with $\mathrm{HCO}_{3}^{-}$), which use $\mathrm{HCO}_{3}^{-}$ for calcification. Prochlorococcus reside mainly in the deep chlorophyll maximum, comprising a rather small portion of the Chl $a$ in the upper $30 \mathrm{~m}$ at BATS (Figs. 2, 4). This could be, however, due to the relatively high $\mathrm{Chl} b$ to $\mathrm{Chl} a$ ratio used in our pigment calculations (Letelier et al., 1993), which is more representative of low-light Prochlorococcus (Partensky et al., 1999). Yet, since $\sim 2005$, Chl $a_{\text {pro }}$ has been more common in the upper $30 \mathrm{~m}$, resulting in an overall positive trend in Chl $a_{\text {pro }}$ over the entire time series $(p<0.001)$.

Consistent with colder, high nutrient environments in which diatoms are normally found, Chl $a_{\text {diatoms }}$ showed a strong positive correlation with $\mathrm{NO}_{3}^{-}$and a negative correlation with temperature (Fig. 3). If predicted trends in sea surface temperature and nutrient supply with further stratification are realized, then diatoms could become a reduced component of the phytoplankton assemblage at BATS (Cabré et al., 2015). Combining fine-scale phytoplankton dynamics from BATS with the satellite record can help to elucidate what changes are occurring over large spatial scales.

\subsection{Trends Chl $a$ and $\mathrm{Chl} a_{\text {hapto }}$ in the subtropical gyre}

Unlike at BATS, Chl $a$ in the North Atlantic subtropical gyre is not increasing (Fig. 9). PIC, on the other hand, shows mainly positive trends over the whole gyre, in agreement with data from BATS - Chl $a_{\text {hapto }}$ shows overall increasing trends, despite some periods of low abundance. Together with an absence of Chl $a$ trend, this implies that coccolithophores are increasing in abundance relative to other types of phytoplankton in the subtropical gyre. Accompanying this conclusion, however, are uncertainties associated with the satellite-derived PIC estimates (see Sect. 4.3 on Limitations of this Study). Even so, ratios relating Chl $a_{\text {hapto }}$ to PIC can further elucidate confidence in satellite-derived PIC estimates.

Data on the amount of Chl $a$ per coccolithophore cell allows for the calculation of cell concentration of coccolithophores in the surface waters at BATS. Using a value of $0.26 \mathrm{pg}$ Chl $a$ per cell (Haxo, 1985), mean coccolithophore cell concentration in the upper $30 \mathrm{~m}$ is $143 \times 10^{3}$ cells L $^{-1}$ (corresponding to the mean value of $37.3 \mu \mathrm{g} \mathrm{Chl} a_{\text {hapto }} \mathrm{m}^{-3}$ in the upper $30 \mathrm{~m}$ ). Employing a ratio of PIC to coccolith of 0.26 (Balch et al., 1992) and considering 15 coccoliths per cell (a minimal monolayer of coccoliths covering the cell) under nutrient replete conditions and $100 \mathrm{coc}-$ coliths per cell under severe nutrient limitation (Paasche, 1998), we arrive at a PIC concentration range of 0.56 to $3.73 \mathrm{mg} \mathrm{PIC} \mathrm{m}^{-3}$. This range corresponds well to the average satellite-derived PIC concentration in the BATS region (Fig. 1a) over the study period: $2.71 \mathrm{mg}$ PIC $\mathrm{m}^{-3}$ for SeaWiFS (standard deviation $=0.50$ ) and $2.66 \mathrm{mg}$ PIC $\mathrm{m}^{-3}$ (standard deviation $=0.39$ ) for MODIS. The relatively high satellite-derived PIC concentration further suggests that coccolithophores may be experiencing nutrient limitation at BATS (and producing additional coccoliths in response; 
Paasche, 1998). Therefore, even given the multiple sources of error involved with satellite-derived PIC estimates and pigment analyses (see below), we feel the strong predominance of positive trends in PIC, along with the BATS Chl $a_{\text {hapto }}$ data, suggests that coccolithophores are proliferating in this region (Fig. 8).

\subsection{Limitations of this study}

There are several caveats of this study that must be discussed before these results can be put into context. First, a primary assumption in this paper is that the haptophyte group is mainly composed of coccolithophores. Though high haptophyte diversity has been reported in open-ocean regimes (Liu et al., 2009), this does not necessarily contradict the assumption that coccolithophores are the dominant type of haptophyte. While several studies describe coccolithophores to be the dominant haptophyte at BATS (see Sect. 2; Lomas and Bates, 2004; Steinberg et al., 2001), this claim remains unsupported by specific data. We use the significant positive correlation between $\mathrm{Chl} a_{\text {hapto }}$ and cell counts from Haidar and Thierstein (2001) to support our assumption that $\mathrm{Chl} a_{\text {hapto }}$ is mainly representative of coccolithophores (Fig. S1). However, as with any study that derives phytoplankton community composition from signature pigments, inherent uncertainties are associated with changes in pigment content within a phytoplankton group over time.

Overall pigment and PIC concentration per coccolithophore cell may be influenced by environmental conditions. For example, photo-acclimation and nutrient limitation can invoke changes in pigment composition or calcification that are not necessarily associated with changes in overall abundance (Behrenfeld et al., 2015; Paasche, 1998). Dominant species shifts within a phytoplankton group could also influence pigment and/or PIC measurements. Nevertheless, given upward trends observed for both Chl $a_{\text {hapto }}$ and PIC (Figs. 5, 8), we feel the most probable explanation of these observations is increases in overall coccolithophore abundance. However, satellite-derived PIC measurements also contain inherent uncertainties.

Radiance-based algorithms for deriving PIC from satellite reflectance data are formulated to capture the light-scattering properties of the numerically dominant coccolithophore, $E$. huxleyi, but also capture detached or detrital coccoliths (Gordon et al., 2001; Balch et al., 2005). PIC concentrations in the North Atlantic subtropical gyre are comparatively low, generally $\sim 2.7 \mathrm{mg} \mathrm{m}^{-3}$, compared to other coccolithophore bloom regions, which have PIC concentrations between 10 and $100 \mathrm{mg} \mathrm{m}^{-3}$ (Balch et al., 2005). The low concentrations of PIC observed in the North Atlantic subtropical gyre could be within background error or nearing the sensitivity threshold of the instrument. Errors in satellite-derived PIC can arise from atmospheric correction, inclusion of other suspended minerals (such as silica; opal contamination), and/or the influence of chlorophyll or colored, dissolved organic matter (see Balch et al., 2005). However, these errors can be minimized by binning in space and time, as we have done in this study (using monthly, $9 \mathrm{~km}$ data rather than daily, $4 \mathrm{~km}$ data). It is also curious that SeaWiFS-derived PIC data better match the Chl $a_{\text {hapto }}$ estimates from BATS than the MODIS PIC (Fig. 5). On the one hand, this may be indicative that other $19^{\prime}$-hex-containing haptophytes were responsible for the increase in Chl $a_{\text {hapto }}$ at BATS during the last several years of the time series. On the other hand, the predominance of upward trends in MODIS-derived PIC for areas around BATS (Fig. 8b, d) suggests increases in calcifying haptophytes (coccolithophores). It should be noted that MODIS PIC from the BATS region (see Fig. 1) still shows a significant correlation with Chl $a_{\text {hapto }}$ (see Sect. 3, Sect. 3.5).

Finally, we are limited in our trend analysis by the length of the time series data. Figure 7 demonstrates that different start and end years can influence the sign and magnitude of our trends in, e.g., Chl $a_{\text {hapto }}$. In this study, we report trends in pigments from 1990 to 2012 and trends in PIC from 1998 to 2014, both of which, when employing the full time series of data, imply increases in coccolithophore populations in the subtropical North Atlantic.

\subsection{Trends in coccolithophore abundance: present and future}

This is not the only study to suggest that coccolithophores are increasing in abundance in the North Atlantic. Using Continuous Plankton Recorder ship measurements, Rivero-Calle et al. (2015) document an increase in coccolithophore occurrence from $\sim 2$ to $>20 \%$ in the North Atlantic from 1965 to 2010, which they attribute to increasing $\mathrm{CO}_{2}$ concentrations. The data region in their study extends from $\sim 40$ to $\sim 65^{\circ} \mathrm{N}$ (subpolar gyre), just north of the subtropical gyre region focused on in this study. Thus, these studies combined add robustness to the conclusion that coccolithophores in the North Atlantic are increasing in abundance and are likely stimulated by additional carbon from anthropogenic sources.

Ocean acidification may eventually hinder the growth and calcification of coccolithophores, however. Recently, Bach (2015) and Bach et al. (2015) introduced the substrateinhibitor ratio, describing the dependence of calcification on $\mathrm{HCO}_{3}^{-}$(the substrate) and $\mathrm{H}^{+}$(the inhibitor) concentrations. When this ratio falls below a critical level (i.e., intercellular to extracellular $\mathrm{H}^{+}$concentration ratio too low) coccolithophore calcification will be hindered, unless they evolve a mechanism for coping with low pH (Bach et al., 2015). Bach et al. (2013) demonstrated that $\mathrm{pH}$ starts to have a negative impact below $\mathrm{pH}_{T} 7.7$, whereas the BATS average $\mathrm{pH}_{T}$ is $\sim 8.1$. Thus, critical $\mathrm{pH}$ levels will not likely happen for several thousand years (Bach et al., 2015). Other factors besides carbonate chemistry, such as light availability, temperature, and nutrients, likely influence coccolithophore growth in present-day oceans. 


\subsection{Potential implications}

Increases in coccolithophore abundance in the North Atlantic could have far-reaching ecological, biogeochemical, and climate effects. A shift in phytoplankton community structure could change trophic dynamics, ultimately resulting in ecosystem shifts (Pörtner et al., 2014). For example, though the evolutionary purpose of coccolithophore shells is unclear, some studies speculate they could protect against grazing (see chapter on functions of coccoliths in Winter and Siesser, 1994). Shifts to relatively more coccolithophores in a phytoplankton assemblage could reduce trophic energy available for grazers. Coccolithophore shells also function as a ballast material, sinking faster due to increased weight of the $\mathrm{CaCO}_{3}$ shell, and sequestering organic matter in the deep ocean (Sarmiento and Gruber, 2006; for a recent study of export at BATS, see Lomas et al., 2010). Increases in coccolithophore abundance may have a positive impact on export production, thus a negative feedback on increasing atmospheric $\mathrm{CO}_{2}$. In addition to bringing carbon to the deep ocean, coccolithophores produce the marine trace gas dimethyl sulfide (DMS; Keller, 1989), which affects cloud formation and climate. Therefore, overall increases in coccolithophore abundance could increase marine DMS production. Furthermore, DMS production by the coccolithophore, E. huxeyi, has been shown to increase with increasing temperature and ambient $\mathrm{CO}_{2}$ (Arnold et al., 2013). Thus, changes in coccolithophore abundance could have a multitude of effects on marine ecosystems in the North Atlantic, as well as global carbon cycling and climate. These effects could be further amplified if other ocean basins show similar shifts in phytoplankton composition.

In the subtropical North Atlantic, the upper mixed layer contains particularly high levels of anthropogenic $\mathrm{CO}_{2}$ (Sabine et al., 2004; Bates et al., 2012). We speculate that this rise in DIC is contributing to the increases in coccolithophore pigments and PIC documented in this study. However, it is not clear if phytoplankton communities in other similar oceanic ecosystems, e.g., the North Pacific subtropical gyre, will show similar changes as atmospheric $\mathrm{CO}_{2}$ concentrations continue to increase and inundate the upper mixed layer. The aforementioned ecosystem and carbon cycle effects of coccolithophore increases could become even more prevalent in the world's ocean, or, alternatively, coccolithophore growth could be further modulated by temperature, nutrients, and light. In any case, monitoring the response of natural coccolithophore populations to increasing DIC/ocean acidification is essential for understanding effects of anthropogenic carbon emissions on the world's oceans.

\section{Conclusions}

In this study, we showed that, based on pigment and satellitederived PIC measurements, coccolithophores appear to be increasing abundance in the subtropical North Atlantic. Coccolithophores seem to be responding positively to additional inorganic carbon in the upper mixed later of the water column, but are also correlated with $\mathrm{NO}_{3}^{-}$. These results complement those of Rivero-Calle et al. (2015), who also document an increase in coccolithophore occurrence in the North Atlantic, albeit farther north, stimulated by anthropogenic $\mathrm{CO}_{2}$ emissions. Increasing coccolithophore abundance is contrary to what numerous laboratory studies have predicted, highlighting the importance of in situ observations. Growth of coccolithophores could, however, be eventually inhibited by decreasing $\mathrm{pH}$ and/or other environmental effects of climate change.

\section{The Supplement related to this article is available online at doi:10.5194/bg-13-1163-2016-supplement.}

Acknowledgements. We would like to thank Rod Johnson, Mike Lomas, and Deborah Steinberg for access to BATS data, and the BATS research group for their sustained efforts collecting data. The SeaWiFs and MODIS particulate inorganic carbon data were obtained from the NASA Ocean Color archive (http://oceancolor.gsfc.nasa.gov). The Fortran 90 code for Mocsy routines to model the ocean carbonate system were obtained from the Mocsy website (http://ocmip5.ipsl.jussieu.fr/mocsy/index.html). Funding for this research was provided by NSF (OCE-1155240; OCE-1258995), NASA (NNX11AF53G), and NOAA (NAO12AR4310058).

Edited by: J.-P. Gattuso

\section{References}

Agawin, N. S. R., Tovar-Sánchez, A., de Zarruk, K. K., Duarte, C. M., and Agustí, S.: Variability in the abundance of Trichodesmium and nitrogen fixation activities in the subtropical NE Atlantic, J. Plankton Res., 35, 1126-1140, 2013.

Andersen, R. A., Bidigare, R. R., Keller, M. D., and Latasa, M.: A comparison of HPLC pigment signatures and electron microscopic observations for oligotrophic waters of the North Atlantic and Pacific Oceans, Deep-Sea Res. Pt. II, 43, 517-537, doi:10.1016/0967-0645(95)00095-X, 1996.

Arnold, H. E., Kerrison, P., and Steinke, M.: Interacting effects of ocean acidification and warming on growth and DMS-production in the haptophyte coccolithophore Emiliania huxleyi, Glob. Change Biol., 19, 1007-1016, doi:10.1111/gcb.12105, 2013.

Bach, L. T.: Reconsidering the role of carbonate ion concentration in calcification by marine organisms, Biogeosciences, 12, 49394951, doi:10.5194/bg-12-4939-2015, 2015. 
Bach, L. T., Mackinder, L. C. M., Schulz, K. G., Wheeler, G., Schroeder, D. C., Brownlee, C., and Riebesell, U.: Dissecting the impact of $\mathrm{CO}_{2}$ and $\mathrm{pH}$ on the mechanisms of photosynthesis and calcification in the coccolithophore Emiliania huxleyi, New Phytol., 199, 121-134, doi:10.1111/nph.12225, 2013.

Bach, L. T., Riebesell, U., Gutowska, M. A., Federwisch, L., and Schulz, K. G.: A unifying concept of coccolithophore sensitivity to changing carbonate chemistry embedded in an ecological framework, Prog. Oceanogr., 135, 125-138, doi:10.1016/j.pocean.2015.04.012, 2015.

Badger, M. R. and Price, G. D.: $\mathrm{CO}_{2}$ concentrating mechanisms in cyanobacteria: molecular components, their diversity and evolution, J. Exp. Bot., 54, 609-622, doi:10.1093/jxb/erg076, 2003.

Balch, W., Gordon, H. R., Bowler, B., Drapeau, D., and Booth, E.: Calcium carbonate measurements in the surface global ocean based on Moderate-Resolution Imaging Spectroradiometer data, J. Geophys. Res.-Oceans, 110, 1978-2012, 2005.

Balch, W. M. and Utgoff, P. E.: Potential Interactions Among Ocean Acidification, Coccolithophores, and the Optical Properties of Seawater, Oceanography, 22, 146-159, 2008.

Balch, W. M., Holligan, P. M., and Kilpatrick, K. A.: Calcification, photosynthesis and growth of the bloom-forming coccolithophore, Emiliania huxleyi, Cont. Shelf Res., 12, 1353-1374, doi:10.1016/0278-4343(92)90059-S, 1992.

Bates, N. R., Best, M. H. P., Neely, K., Garley, R., Dickson, A. G., and Johnson, R. J.: Detecting anthropogenic carbon dioxide uptake and ocean acidification in the North Atlantic Ocean, Biogeosciences, 9, 2509-2522, doi:10.5194/bg-9-2509-2012, 2012.

Bates, N. R., Asto, Y., Church, M., Currie, K., Dore, J., GonzálezDávila, M., Lorenzoni, L., Muller-Karger, F., Olafsson, J., and Santana-Casiano, J.: A time-series view of changing ocean chemistry due to ocean uptake of anthropogenic $\mathrm{CO}_{2}$ and ocean acidification, Oceanography, 27, 126-141, 2014.

Beaufort, L., Probert, I., de Garidel-Thoron, T., Bendif, E. M., RuizPino, D., Metzl, N., Goyet, C., Buchet, N., Coupel, P., Grelaud, M., Rost, B., Rickaby, R. E. M., and de Vargas, C.: Sensitivity of coccolithophores to carbonate chemistry and ocean acidification, Nature, 476, 80-83, doi:10.1038/nature10295, 2011.

Behrenfeld, M. J., O’Malley, R. T., Boss, E. S., Westberry, T. K., Graff, J. R., Halsey, K. H., Milligan, A. J., Siegel, D. A., and Brown, M. B.: Revaluating ocean warming impacts on global phytoplankton, Nature Clim. Change, doi:10.1038/nclimate2838, online first, 2015.

Boyd, P. W., Lennartz, S. T., Glover, D. M., and Doney, S. C.: Biological ramifications of climate-change-mediated oceanic multi-stressors, Nature Clim. Change, 5, 71-79, doi:10.1038/nclimate2441, 2015.

Brown, Z. W. and Arrigo, K. R.: Contrasting trends in sea ice and primary production in the Bering Sea and Arctic Ocean, ICES Journal of Marine Science: Journal du Conseil, 69, 1180-1193, 2012.

Cabré, A., Marinov, I., and Leung, S.: Consistent global responses of marine ecosystems to future climate change across the IPCC AR5 earth system models, Clim. Dynam., 45, 1253-1280, doi:10.1007/s00382-014-2374-3, 2015.

Carpenter, E., Oneil, J., Dawson, R., Capone, D., Siddiqui, P., Roenneberg, T., and Bergman, B.: The tropical diazotrophic phytoplankter Trichodesmium-biological characteristics of two common species, Mar. Ecol. Prog. Ser., 95, 295-304, 1993.
Carpenter, E. J., Subramaniam, A., and Capone, D. G.: Biomass and primary productivity of the cyanobacterium Trichodesmium spp. in the tropical N Atlantic ocean, Deep-Sea Res. Pt. I, 51, 173203, doi:10.1016/j.dsr.2003.10.006, 2004.

Cortés, M. Y., Bollmann, J., and Thierstein, H. R.: Coccolithophore ecology at the HOT station ALOHA, Hawaii, Deep-Sea Res. Pt. II, 48, 1957-1981, 2001.

Dandonneau, Y., Montel, Y., Blanchot, J., Giraudeau, J., and Neveux, J.: Temporal variability in phytoplankton pigments, picoplankton and coccolithophores along a transect through the North Atlantic and tropical southwestern Pacific, Deep-Sea Res. Pt. I, 53, 689-712, doi:10.1016/j.dsr.2006.01.002, 2006.

Delille, B., Harlay, J., Zondervan, I., Jacquet, S., Chou, L., Wollast, R., Bellerby, R. G., Frankignoulle, M., Borges, A. V., Riebesell, U., and Gattuso, J. P.: Response of primary production and calcification to changes of $\mathrm{pCO}_{2}$ during experimental blooms of the coccolithophorid Emiliania huxleyi, Global Biogeochem. Cy., 19, GB2023, doi:10.1029/2004GB002318, 2005.

Doney, S. C., Fabry, V. J., Feely, R. A., and Kleypas, J. A.: Ocean acidification: the other $\mathrm{CO}_{2}$ problem, Annu. Rev. Mar. Sci., 1, 169-192, 2009.

Feng, Y., Hare, C., Leblanc, K., Rose, J. M., Zhang, Y., DiTullio, G. R., Lee, P. A., Wilhelm, S. W., Rowe, J. M., Sun, J., Nemcek, N., Gueguen, C., Passow, U., Benner, I., Brown, C., and Hutchins, D. A.: Effects of increased $\mathrm{pCO}_{2}$ and temperature on the North Atlantic spring bloom. I. The phytoplankton community and biogeochemical response, Mar. Ecol. Prog. Ser., 388, 13-25, 2009.

Freeman, N. M. and Lovenduski, N. S.: Decreased calcification in the Southern Ocean over the satellite record, Geophys. Res. Lett. 42, 1834-1840, doi:10.1002/2014GL062769, 2015.

Fu, F.-X., Warner, M. E., Zhang, Y., Feng, Y., and Hutchins, D. A.: Effects of increased temperature and $\mathrm{CO}_{2}$ on photosynthesis, growth, and elemental ratios in marine Synechococcus and Prochlorococcus (Cyanobacteria), J. Phycol., 43, 485-496, doi:10.1111/j.1529-8817.2007.00355.x, 2007.

Giovannoni, S. J. and Vergin, K. L.: Seasonality in ocean microbial communities, Science, 335, 671-676, 2012.

Gordon, H. R., Boynton, G. C., Balch, W. M., Groom, S. B., Harbour, D. S., and Smyth, T. J.: Retrieval of coccolithophore calcite concentration from SeaWiFS Imagery, Geophys. Res. Lett., 28, 1587-1590, doi:10.1029/2000GL012025, 2001.

Gradoville, M. R., White, A. E., Böttjer, D., Church, M. J., and Letelier, R. M.: Diversity trumps acidification: Lack of evidence for carbon dioxide enhancement of Trichodesmium community nitrogen or carbon fixation at Station ALOHA, Limnol. Oceanogr., 59, 645-659, 2014.

Gruber, N.: Warming up, turning sour, losing breath: ocean biogeochemistry under global change, Philos. T. R. Soc. A, 369, 19801996, 2011.

Haidar, A. T. and Thierstein, H. R.: Coccolithophore dynamics of Bermuda (N. Atlantic), Deep-Sea Res. Pt. II, 48, 1925-1956, 2001.

Haxo, F. T.: Photosynthetic action spectrum of the coccolithophorid, Emiliania huxleyi (haptophyceae): 19'Hexanoyloxyfucoxanthin, J. Phycol., 21, 282-287, doi:10.1111/j.0022-3646.1985.00282.x, 1985.

Hutchins, D. A., Fu, F.-X., Zhang, Y., Warner, M. E., Feng, Y., Portune, K., Bernhardt, P. W., and Mulholland, M. R.: $\mathrm{CO}_{2}$ 
control of Trichodesmium $\mathrm{N}_{2}$ fixation, photosynthesis, growth rates, and elemental ratios: Implications for past, present, and future ocean biogeochemistry, Limnol. Oceanogr., 52, 1293-1304, doi:10.4319/lo.2007.52.4.1293, 2007.

Iglesias-Rodriguez, M. D., Halloran, P. R., Rickaby, R. E. M., Hall, I. R., Colmenero-Hidalgo, E., Gittins, J. R., Green, D. R. H., Tyrrell, T., Gibbs, S. J., von Dassow, P., Rehm, E., Armbrust, E. V., and Boessenkool, K. P.: Phytoplankton Calcification in a High- $\mathrm{CO}_{2}$ World, Science, 320, 336-340, doi:10.1126/science.1154122, 2008.

Keller, M. D.: Dimethyl Sulfide Production and Marine Phytoplankton: The Importance of Species Composition and Cell Size, Biol. Oceanogr., 6, 375-382, 1989.

Letelier, R. M., Bidigare, R. R., Hebel, D. V., Ondrusek, M., Winn, C. D., and Karl, D. M.: Temporal variability of phytoplankton community structure based on pigment analysis, Limnol. Oceanogr., 38, 1420-1437, doi:10.4319/lo.1993.38.7.1420, 1993.

Liu, H., Probert, I., Uitz, J., Claustre, H., Aris-Brosou, S., Frada, M., Not, F., and de Vargas, C.: Extreme diversity in noncalcifying haptophytes explains a major pigment paradox in open oceans, P. Natl. Acad. Sci., 106, 12803-12808, doi:10.1073/pnas.0905841106, 2009.

Lomas, M., Bates, N., Johnson, R., Knap, A., Steinberg, D., and Carlson, C.: Two decades and counting: 24-years of sustained open ocean biogeochemical measurements in the Sargasso Sea, Deep-Sea Res. Pt. II, 93, 16-32, doi:10.1016/j.dsr2.2013.01.008, 2013.

Lomas, M. W. and Bates, N. R.: Potential controls on interannual partitioning of organic carbon during the winter/spring phytoplankton bloom at the Bermuda Atlantic time-series study (BATS) site, Deep-Sea Res. Pt. I, 51, 1619-1636, 2004.

Lomas, M. W., Steinberg, D. K., Dickey, T., Carlson, C. A., Nelson, N. B., Condon, R. H., and Bates, N. R.: Increased ocean carbon export in the Sargasso Sea linked to climate variability is countered by its enhanced mesopelagic attenuation, Biogeosciences, 7, 57-70, doi:10.5194/bg-7-57-2010, 2010.

Lueker, T. J., Dickson, A. G., and Keeling, C. D.: Ocean $p \mathrm{CO}_{2}$ calculated from dissolved inorganic carbon, alkalinity, and equations for $\mathrm{K}_{1}$ and $\mathrm{K}_{2}$ : validation based on laboratory measurements of $\mathrm{CO}_{2}$ in gas and seawater at equilibrium, Mar. Chem., 70, 105-119, doi:10.1016/S0304-4203(00)00022-0, 2000.

Mackey, K., Morris, J., Morel, F., and Kranz, S.: Response of photosynthesis to ocean acidification, Oceanography, 28, 74-91, doi:10.5670/oceanog.2015.33, 2015.

Monterey, G. and Levitus, S.: Seasonal variability of mixed layer depth for the world ocean, NOAA Atlas NESDIS 14, U.S. Department of Commerce, 1997.

Orcutt, K. M., Lipschultz, F., Gundersen, K., Arimoto, R., Michaels, A. F., Knap, A. H., and Gallon, J. R.: A seasonal study of the significance of $\mathrm{N}_{2}$ fixation by Trichodesmium spp. at the Bermuda Atlantic Time-series Study (BATS) site, Deep-Sea Res. Pt. II, 48, 1583-1608, doi:10.1016/S0967-0645(00)00157-0, 2001.

Orr, J. C. and Epitalon, J.-M.: Improved routines to model the ocean carbonate system: mocsy 2.0, Geosci. Model Dev., 8, 485-499, doi:10.5194/gmd-8-485-2015, 2015.

Orr, J. C., Epitalon, J.-M., and Gattuso, J.-P.: Comparison of ten packages that compute ocean carbonate chemistry, Biogeosciences, 12, 1483-1510, doi:10.5194/bg-12-1483-2015, 2015.
Paasche, E.: Roles of nitrogen and phosphorus in coccolith formation in Emiliania huxleyi (Prymnesiophyceae), European J. Phycol., 33, 33-42, doi:10.1080/09670269810001736513, 1998.

Partensky, F., Hess, W. R., and Vaulot, D.: Prochlorococcus, a marine photosynthetic prokaryote of global significance, Microbiology and Molecular Biology Reviews, 63, 106-127, 1999.

Pörtner, H.-O., Karl, D., Boyd, P., Cheung, W., Lluch-Cota, S., Nojiri, Y., Schmidt, D., and Zavialov, P.: Climate Change 2014: Impacts, Adaptation, and Vulnerability. Part A: Global and Sectoral Aspects. Contribution of Working Group II to the Fifth Assessment Report of the Intergovernmental Panel of Climate Change: Ocean systems, 411-484, Cambridge University Press, Cambridge, United Kingdom and New York, NY, USA, 2014.

Riebesell, U.: Effects of $\mathrm{CO}_{2}$ enrichment on marine phytoplankton, J. Oceanogr., 60, 719-729, doi:10.1007/s10872-004-5764-z, 2004.

Riebesell, U., Zondervan, I., Rost, B., Tortell, P. D., Zeebe, R. E., and Morel, F. M. M.: Reduced calcification of marine plankton in response to increased atmospheric $\mathrm{CO}_{2}$, Nature, 407, 364-367, doi:10.1038/35030078, 2000.

Riebesell, U., Schulz, K. G., Bellerby, R. G. J., Botros, M., Fritsche, P., Meyerhofer, M., Neill, C., Nondal, G., Oschlies, A., Wohlers, J., and Zollner, E.: Enhanced biological carbon consumption in a high $\mathrm{CO}_{2}$ ocean, Nature, 450, 545-548, doi:10.1038/nature06267, 2007.

Riegman, R., Stolte, W., Noordeloos, A. A. M., and Slezak, D.: Nutrient uptake and alkaline phosphatase (EC 3:1:3:1) activity of Emiliania huxleyi (PRYMNESIOPHYCEAE) during growth under $\mathrm{N}$ and $\mathrm{P}$ limitation in continuous cultures, J. Phycol., 36, 8796, doi:10.1046/j.1529-8817.2000.99023.x, 2000.

Rivero-Calle, S., Gnanadesikan, A., Del Castillo, C. E., Balch, W. M., and Guikema, S. D.: Multidecadal increase in North Atlantic coccolithophores and the potential role of rising $\mathrm{CO}_{2}$, Science, 350, 1533-1537, doi:10.1126/science.aaa8026, 2015.

Rost, B., Riebesell, U., Burkhardt, S., and Sültemeyer, D.: Carbon acquisition of bloom-forming marine phytoplankton, Limnol. Oceanogr., 48, 55-67, doi:10.4319/lo.2003.48.1.0055, 2003.

Sabine, C. L., Feely, R. A., Gruber, N., Key, R. M., Lee, K., Bullister, J. L., Wanninkhof, R., Wong, C. S., Wallace, D. W. R., Tilbrook, B., Millero, F. J., Peng, T.-H., Kozyr, A., Ono, T., and Rios, A. F.: The Oceanic Sink for Anthropogenic $\mathrm{CO}_{2}$, Science, 305, 367-371, doi:10.1126/science.1097403, 2004.

Sarmiento, J. L. and Gruber, N.: Ocean Biogeochemical Dynamics, Princeton University Press, 2006.

Schlüter, L., Lohbeck, K. T., Gutowska, M. A., Groger, J. P., Riebesell, U., and Reusch, T. B. H.: Adaptation of a globally important coccolithophore to ocean warming and acidification, Nature Clim. Change, 4, 1024-1030, doi:10.1038/nclimate2379, 2014.

Sciandra, A., Harlay, J., Lefèvre, D., Lemée, R., Rimmelin, P., Denis, M., and Gattuso, J.-P.: Response of coccolithophorid Emiliania huxleyi to elevated partial pressure of $\mathrm{CO}_{2}$ under nitrogen limitation, Mar. Ecol. Prog. Ser., 261, 111-122, 2003.

Sett, S., Bach, L. T., Schulz, K. G., Koch-Klavsen, S., Lebrato, M., and Riebesell, U.: Temperature Modulates Coccolithophorid Sensitivity of Growth, Photosynthesis and Calcification to Increasing Seawater $p \mathrm{CO}_{2}$, PLoS ONE, 9, e88308, doi:10.1371/journal.pone.0088308, 2014.

Snow, J. T., Schlosser, C., Woodward, E. M. S., Mills, M. M., Achterberg, E. P., Mahaffey, C., Bibby, T. S., and Moore, C. M.: 
Environmental controls on the biogeography of diazotrophy and Trichodesmium in the Atlantic Ocean, Global Biogeochem. Cy., 29, 865-884, doi:10.1002/2015GB005090, 2015.

Steinberg, D. K., Carlson, C. A., Bates, N. R., Johnson, R. J., Michaels, A. F., and Knap, A. H.: Overview of the US JGOFS Bermuda Atlantic Time-series Study (BATS): a decade-scale look at ocean biology and biogeochemistry, Deep-Sea Res. Pt II, 48, 1405-1447, 2001.

Thierstein, H. R. and Young, J. R.: Coccolithophores: from molecular processes to global impact, Springer Science \& Business Media, 2004.

Tyrrell, T. and Taylor, A.: A modelling study of Emiliania huxleyi in the NE Atlantic, J. Marine Syst., 9, 83-112, 1996.

Van Lenning, K., Probert, I., Latasa, M., Estrada, M., and Young, J. R.: Pigment diversity of coccolithophores in relation to taxonomy, phylogeny and ecological preferences, in: Coccolithophores, 51-73, Springer, 2004.
Visbeck, M. H., Hurrell, J. W., Polvani, L., and Cullen, H. M.: The North Atlantic Oscillation: Past, present, and future, P. Natl. Acad. Sci., 98, 12876-12877, doi:10.1073/pnas.231391598, 2001.

Winter, A. and Siesser, W. G. (Eds.): Coccolithophores, Cambridge University Press, Cambridge, United Kingdom and New York, NY, USA, 1994.

Wright, S. W. and van den Enden, R. L.: Phytoplankton community structure and stocks in the East Antarctic marginal ice zone (BROKE survey, January-March 1996) determined by CHEMTAX analysis of HPLC pigment signatures, Deep-Sea Res. Pt II, 47, 2363-2400, doi:10.1016/S0967-0645(00)00029-1, 2000.

Zapata, M., Jeffrey, S. W., Wright, S. W., Rodríguez, F., Garrido, J. L., and Clementson, L.: Photosynthetic pigments in 37 species (65 strains) of Haptophyta: implications for oceanography and chemotaxonomy, Mar. Ecol. Prog. Ser., 270, 83-102, 2004. 